\title{
Molecular basis of basal cell carcinoma*
}

\author{
Erik Montagna ${ }^{1}$
}

\author{
Otávio Sérgio Lopes ${ }^{2,3}$
}

DOI: http:/ / dx.doi.org/10.1590/abd1806-4841.20176544

\begin{abstract}
Basal cell carcinoma is the most common cancer, presenting low mortality but high morbidity, and it has as risk factor exposure to sunlight, especially UVB spectrum. The most important constitutional risk factors for basal cell carcinoma development are clear phototypes (I and II, Fitzpatrick classification), family history of basal cell carcinoma (30-60\%), freckles in childhood, eyes and light hair. The environmental risk factor better established is exposure to ultraviolet radiation. However, different solar exposure scenarios probably are independent risk factors for certain clinical and histological types, topographies and prognosis of this tumor, and focus of controversy among researchers. Studies confirm that changes in cellular genes Hedgehog signaling pathway are associated with the development of basal cell carcinoma. The cellular Hedgehog signaling pathway is activated in organogenesis, but is altered in various types of tumors.
\end{abstract}

Keywords: Carcinoma, basal cell; Genetics; Hedgehog protein

\section{INTRODUCTION}

Non-melanoma skin cancers (NMSC) are the most common form of human skin cancer. The majority of NMSC are basal cell carcinoma (BCC) and squamous cell carcinoma (SCC), with an incidence of 1:4 in immunocompetent patients. ${ }^{1}$ However, there is no compulsory registration of $\mathrm{BCC}$ in Brazil, and many studies have grouped BCC and SCC in their reports. ${ }^{2}$ BCC has an estimated risk of 56 new cases per 100,000 men and 61 per 100,000 women. However, rates vary according to the region and the ethnic composition of the population. ${ }^{3}$ There is a greater involvement of men than women (1.5-2:1), probably due to professional reasons, and the male gender is also associated with a higher number of tumors. ${ }^{4,5}$ BCC is responsible for $80 \%$ of NMSC, being more frequent in patients aged $<40$ years, although mean age at first diagnosis is approximately 60 years. ${ }^{6,7}$

The most important constitutional risk factors for BCC development are clear phototypes (I and II, Fitzpatrick's classification), positive family history of BCC (30-60\%), freckles in childhood, light eyes and hair. ${ }^{8,9,10}$ The best established environmental risk factor is exposure to ultraviolet radiation. However, different sun exposure profiles are probably independent risk factors for certain clinical and histological types, topographies and prognosis of this tumor, being the focus of controversy between researchers.

Ultraviolet B (UVB) radiation generates mutagenic photoproducts in DNA, such as cyclodipyrimidine dimers, as well as mutations in important regulatory genes of cellular functions, such as tumor suppressor gene TP53 (tumor protein p53 in 17p13.1, Gene ID: 7157). Apoptosis of mutated keratinocytes (sunburn cells) after exposure to ultraviolet rays is evidence of their carcinogenic potential. Ultraviolet A (UVA) radiation presents an indirect effect generating cytotoxic and mutagenic free radicals, favoring the effects of UVB. In addition, ultraviolet radiation has immunosuppressive action on the skin, compromising local antitumor surveillance activity of dendritic cells. ${ }^{3}$

Ethnic, cultural and occupational aspects should also interfere with the epidemiological patterns of BCC in different countries. ${ }^{10}$ Other risk factors include immunosuppression, exposure to arsenic, scars and hereditary diseases such as Gorlin-Goltz syndrome (basal cell nevus syndrome) and xeroderma pigmentosum. ${ }^{10,11}$

There are many histological subtypes, however a simplified division classifies BCC into three subtypes: superficial, nodular and infiltrative. ${ }^{12,13}$ BCCs have low metastatic potential and in most cases can be treated with local therapies such as surgical excision, photodynamic therapy, cryotherapy or topical imiquimod. ${ }^{14}$ Occurrence of consecutive tumors is frequent, and recurrence is more common in the first year. Risk of a new lesion in three years is $27 \%$ to $44 \%$, reaching up to $50 \%$ in five years and $90 \%$ in ten years. Male gender, age over 60 years, trunk location, superficial type BCC at histopathological examination and presence of multiple actinic keratoses in the skin are predictive elements for the appearance of new lesions. ${ }^{8,10,14}$

Clinically, BCCs are divided into five types: nodule-ulcerative, pigmented, sclerodermiform or fibrosing, superficial and fibroepithelioma, although there is disagreement in the classifications according to some authors. ${ }^{15-20}$ BCC favors photoexposed areas of the integument. It is located in approximately $80 \%$ of the cases on

Received on 30.09.2016

Approved by the Advisory Board and accepted for publication on 22.01.2017

* Study conducted at Faculdade de Medicina do ABC (FMABC) - Santo André (SP), Brasil.

Financial support: none.

Conflict of interest: none.

Postgraduate, Research and Innovation Center, Faculdade de Medicina do ABC (FMABC) - Santo André (SP), Brazil.

Research Center of the Clínica Dermatológica Santa Catarina - João Pessoa (PB), Brazil.

Departament of Dermatology of Faculty of Medical Sciences of Santa Casa de São Paulo (FCMSCSP) - São Paulo (SP), Brazil.

(C)2017 by Anais Brasileiros de Dermatologia 
the face (30\% on the nasal region) and cervical region. ${ }^{17,21}$ Trunk involvement occurs in 15-43\% of cases. ${ }^{22}$ Occurrence of BCC in areas less exposed to sun is of approximately $20 \%$ of cases. They are usually of greater diameter due to delayed diagnosis, and can present with worse prognosis, surgical morbidity and metastases..$^{23}$ Mean duration of the lesions, from onset to diagnosis, is 37.1 months for both sexes. ${ }^{19}$ Cure rates exceed $90 \%$ with excisional surgical treatment, and BCC-specific mortality is less than $0.1 \%$. The incidence of BCC metastases is rare and ranges from $0.0028 \%$ to $0.55 \%$. $8,10,24$

BCC was primarily described by Jacob in 1827, who named it ulcus rodens, and its current nomenclature was proposed by Krompecher in $1903 .{ }^{25}$ There are no precursor lesions described for BCC, and the cells involved in their origin are controversial. ${ }^{8,10}$ There is evidence of the origin from immature pluripotent cells of the interfollicular epidermis and cells present in the outer sheath of the hair follicle, based on experiments of activation of the Hedgehog pathway in different compartments of the epidermis and on the expression of follicular pattern cytokeratins, which has defined it as malignant neoplasm of follicular germ cells (trichoblasts). ${ }^{26,27}$ In addition, there is association of BCC with abnormalities in the embryonic follicular development gene, SHH (Sonic Hedgehog in 7q36, Gene ID: 6469), a hypothesis strengthened by the rarity of palmoplantar and mucosal lesions where no hair follicles are found. ${ }^{10,28,29}$

\section{HEDGEHOG SIGNALING PATHWAY}

Hedgehog (Hh) signaling pathway is a developmental pathway that was originally identified in Drosophila melanogaster, which is fundamental for appropriate formation of the segments, determining the anterior-posterior corporal axis. ${ }^{30-32}$ Hedgehog genes are highly conserved from Drosophila melanogaster to humans and are considered key regulators of embryonic development. ${ }^{33}$ Hh signaling in mammalian cells is mediated by Hh ligands, such as Sonic Hedgehog (SHH) ${ }^{34}$ Sonic Hedgehog/ Patched signaling controls cells destiny, standardization and growth of numerous tissues. ${ }^{35}$ Post-embryonic activity of $\mathrm{Hh}$ signaling pathway is normal only in hair follicles and skin cells. ${ }^{31}$ In adults, Hh pathway remains active in a number of stem cells and during tissue regeneration. ${ }^{36}$

In humans, loss of Hh function during development can lead to severe effects, resulting in insufficient separation of the cerebral hemispheres, a condition known as holoprosencephaly. ${ }^{37}$

Activation of Hh pathway has been implicated in the tumorigenesis of a large number of human cancers, including medulloblastoma, basal cell carcinomas, leukemia, lung, gastrointestinal, ovary, breast and prostate cancers, since Hh plays a central role in control of the proliferation and differentiation of embryonic stem cells and adult stem cells. ${ }^{38-42}$ In addition, Hh signaling pathway is closely linked to many other signaling pathways, such as Wnt/ betacatenin, TGF-beta/BMP, Notch and FGF pathways, all of which are deeply involved in tissue morphogenesis and homeostasis, organogenesis, and renewal of stem cells in adults. ${ }^{43}$

Mutations occurring in the Hedgehog $(\mathrm{Hh})$ pathways genes in BCCs mainly involve the encoders of the homologous $(\mathrm{PTCH})$ and the deleted homologous (SMO). Several animal models have demonstrated the functional relevance of genetic alterations in the Hh pathway during tumorigenesis. Recently, target therapy has be- come available commercially and in the context of human clinical trials. Interestingly, inhibitors of Hh pathway not only suppress BCC progression, but also help promote immune responses.

Hh pathway plays a crucial role in patterns of development and organogenesis in the early stages and is largely inactive in adults except for its tissue repair and maintenance function. ${ }^{44}$ Central components of Hh pathway consist of three secreted ligands (Sonic $\mathrm{HH}$, Indiana $\mathrm{HH}$ and Desert $\mathrm{HH})$, a negative regulation receptor $(\mathrm{PTCH})$, a positive regulatory receptor $(S M O)$, glioma associated oncogenic factors (GLI), and, finally, transcription factors (Gli1, Gli2 and Gli3). ${ }^{45}$ The signaling mechanism of Hh by means of SMO has been studied. In the absence of the Hh-binding agent, PTCH suppresses SMO activity, preventing trafficking and insertion into the cellular cilia. GLI transcription factors are sequestered in the cytoplasm by various mediator proteins, including protein kinase A (PKA). ${ }^{46}$ GLI undergoes specific cleavage and the resulting repressor moves to the nucleus and inhibits the translation of Hh target genes. Upon binding to the receptor, $\mathrm{PTCH}$ is displaced from the cilia, thus allowing the accumulation and activation of SMO. When activated, GLIs are the final effectors of the pathway and, when translocated to the nucleus, induce the expression of several context-specific genes that regulate cell differentiation, proliferation and survival. ${ }^{47}$

Relation between cancer and Hh pathway activation has been examined from the report of germinal mutations of function loss in PTCH in patients with Gorlin syndrome (BCNS syndrome, Gorlin). ${ }^{48}$ BCNS is an autosomal dominant disease characterized by multiple developmental abnormalities and predisposition to tumors, specifically BCC, medulloblastoma (MB), embryonal rhabdomyosarcoma, and meningioma. ${ }^{49}$ Somatic mutations in $\mathrm{PTCH}$ were identified in $90 \%$ of sporadic BCCs, and function gain mutations in SMO were detected in BCCs. ${ }^{50}$ In particular, recurrent mutations in SMO and functional studies have demonstrated that these mutations lead to aberrant activation of Hh signaling and promote tumor development. ${ }^{51}$ Somatic mutations in PTCH have also been detected in other tumors, such as ovary and endometrium. ${ }^{52}$

In addition to the SMO-dependent pathway, phosphatidylinositol-3-kinase (PI3K) also promotes $\mathrm{Hh}$ signaling in oncogenesis. S6-kinase 1 (S6K1) and atypical protein kinase $\mathrm{C}(\mathrm{aPKC})$, components that are downstream of PI3K, promote GLI-dependent transcription. S6K1 is also downstream of the target mammalian rapamycin pathway (mTOR) and has been found to be elevated in esophageal cancer resistant to SMO antagonists. ${ }^{53}$ In addition, PI3K may promote the activation of 3-phosphoinosinoside-dependent kinase 1 (PDK1), which promotes mTOR and activation of S6K1. S6K1 promotes GLI-dependent transcription by Gli1 phosphorylation, which prevents an interaction that allows GLI to enter the nucleus and activate target genes. An Hh target gene is aPKC that phosphorylates Gli1 at sites other than S6K1, activating Gli1 binding to DNA, which can generate positive feedback that amplifies GLI-dependent transcription in BCC. ${ }^{53}$

The first well-studied therapy targeting the Hh pathway was cyclopamine, a steroidal alkaloid from the Veratum californicum plant, which acted directly on a Sonic Hh pathway, known as definer of cyclophopone phenotype in mice. ${ }^{54}$ This established an important connection between cyclopamine and activation of the 
Hh pathway. ${ }^{55}$ Thus, a large amount of SMO antagonist molecules, including vismodegib, has been identified as effective in vitro.

Vismodegib is effective in suppressing BCC growth, both as tumoricide and as tumoristic. Recurrences of BCC arise after cessation of treatment with vismodegib, suggesting that the more efficient use of vismodegib as a therapeutic agent is to shrink tumors to a manageable level and then to promote surgical removal of the tumor or any other clone remaining. A recent study on the efficacy and safety of vismodegib in patients with BCC (STEVIE study) brought significant data and made room for the development of other SMO inhibitors. Clinical trials to treat advanced or metastatic BCC, including sonidegib (LDE 225), erismodegib, XL-139, LEQ 506 , itraconazole, and saridegib. ${ }^{56}$ In addition, there are several candidate components for the treatment of BCC, such as BEZ 235, a mTOR signaling inhibitor. ${ }^{57,58}$

\section{GENETICS OF BASAL CELL CARCINOMA}

The development of a BCC results from the interaction between several genes and environmental factors. Between $30 \%$ and $75 \%$ of sporadic cases are associated with mutation of patched hedgehog 1 and 2 tumor suppressor genes, PTCH1 in 9q22.3 (Gene ID: 5727) and PTCH2 in 1p34.1 (Gene ID: 8643), but other genetic alterations were already described. ${ }^{59}$

PTCH1 gene encodes a transmembrane receptor for $\mathrm{SHH}$ and Hh pathway proteins, repressing the functions of another protein lo- cated in the membrane, the smoothened, encoded by the gene SMO (Gene ID: 6608 in 7q32.3), forming a complex in the cell membrane, which has a suppressive effect on growth signal transduction. ${ }^{59}$

When mutations in the PTCH1 gene occur, its inhibitory effect on $S M O$ is lost, since activation of smoothened protein activates GLI-1 factor, which induces the transcription of several oncogenes involved in the development of BCC and other neoplasias, resulting in proliferation and cell stimulation. ${ }^{10} \mathrm{SHH}$ ligand, when binding to $P$ TCH, also disrupts this inhibition, allowing signal transduction and causing the same effects. ${ }^{59}$ Mutations in SMO gene are present in $10-21 \%$ of sporadic BCCs and in TP53 gene (tumor protein p53 in 17p13.1, Gene ID: 7157) in more than $50 \%$ of cases, although the latter is more related to the progression than to the genesis of BCC. $8,28,60$

Animal models have been developed from transgenic mice that overexpress the smoothened protein in tissues. These animals present, in addition to multiple BCCs, numerous bone alterations, simulating basal cell nevus syndrome. ${ }^{61,62}$ Other changes were identified in patients with BCC from population gene sequencing studies, such as mutations in pigmentary genes, melanocortin 1 receptor gene (MC1R in 16q24.3, gene ID: 4157), associated with melanoma and BCC susceptibility. ${ }^{63}$ In addition, single nucleotide polymorphisms (SNPs) were also associated with BCC, such as rs11170164 in the KRT5 gene, variants in 9p21 near CDKN2A and CDKN2B, as well as rs157935 [T] in 7q32 near KLF14. A variant in the SLC45A2 gene was also associated with risk of both BCC and SCC. ${ }^{64}$

\section{REFERENCES}

1. Bahner JD, Bordeaux JS. Non melanoma skin cancers: Photodynamic therapy, cryotherapy, 5 fluorouracil, imiquimod, diclofenac, or what? Facts and controversies. Clin Dermatol. 2013;31:792-8.

2. Chinem VP, Miot HA. Epidemiology of basal cell carcinoma. An Bras Dermatol. 2011;86:292-305.

3. Sociedade Brasileira de Dermatologia SBD. Perfil nosológico das consultas dermatológicas no Brasil. An Bras Dermatol. 2006; 81:549-58.

4. Roewert-Huber J, Lange-Asschenfeldt B, Stockfleth E, Kerl H. Epidemiology and aetiology of basal cell carcinoma. Br J Dermatol. 2007;157:47-51.

5. Hoban PR, Ramachandran S, Strange RC. Environment, phenotype and genetics: risk factors associated with BCC of the skin. Expert Rev Anticancer Ther. 2002;2:570-9.

6. Madan V, Lear JT, Szeimies RM. Non melanoma skin cancer. Lancet. 2010;375:673-85.

7. Christenson LJ, Borrowman TA, Vachon CM, Tollefson MM, Otley CC, Weaver $\mathrm{AL}$, et al. Incidence of basal cell and squamous cell carcinomas in a population younger than 40 years. JAMA. 2005 Aug 10;294:681-90.

8. Roewert-Huber J, Lange-Asschenfeldt B, Stockfleth E, Kerl H. Epidemiology and aetiology of basal cell carcinoma. Br J Dermatol. 2007;157:47-51.

9. Lear W, Dahlke E, Murray CA. Basal cell carcinoma: review of epidemiology, pathogenesis, and associated risk factors. J Cutan Med Surg. 2007;11:19-30.

10. Chinem VP, Miot HA. Epidemiologia do carcinoma basocelular. An Bras Dermatol. 2011;86:292-305.

11. Dummer R, Karpova MB, Barysch MJ. Basal cell carcinomas: Molecular abnormalities and molecularly targeted therapies. Expert Rev Dermatol. 2009;4:355 369 .

12. Rippey JJ. Why classify basal cell carcinomas? Histopathology. 1998;32:393-8.

13. Rubin Al, Chen EH, Ratner D. Basal cell carcinoma. N Engl J Med. 2005;353:2262-9

14. Richmond-Sinclair NM, Pandeya N, Williams GM, Neale RE, van der Pols JC, Green AC. Clinical signs of photodamage are associated with basal cell carcinoma multiplicity and site: A 16-year longitudinal study. Int J Cancer. 2010;127:2622-9.

15. Minelli L. Estudo estatístico do carcinoma basocelular em Londrina, Paraná, Brasil. An Bras Dermatol. 1987;62:321-5

16. Sobral Filho JF, Botelho G, Ramalho GL, Farias RL, Oliveira Júnior R. Variáveis epidemiológicas do carcinoma basocelular na Paraíba. CCS. 1995;14:38-45.

17. Kopke LFF, Schmidt SM. Carcinoma basocelular. An Bras Dermatol. 2002;77:249-85.

18. Lascano AR, Kuznitzky R, Garay I, Ducasse C, Albertini R. Factores de riesgo para carcinoma basocelular. Estudio de casos-controles en Cordoba. Medicina (B Aires). 2005;65:495-500.

19. Mantese SAO, Berbert ALCV, Gomides MDA, Rocha A. Carcinoma basocelular - Análise de 300 casos observados em Uberlândia - MG. An Bras Dermatol. 2006;81:136-42.

20. Bernard P, Dupuy A, Sasco A, Brun P, Duru G, Nicoloyannis N, et al. Basal cell carcinomas and actinic keratoses seen in dermatological practice in France: a cross-sectional survey. Dermatology. 2008;216:194-9.

21. Sarfati B, Lazar CC, Goubin I, Zwillinger N, Lorenceau B. Basal-cell carcinoma of fingers: A rare location not to be ignored. Ann Chir Plast Esthet. 2010;55:74-7.

22. Lear JT, Smith AG, Strange RC, Fryer AA. Patients with truncal basal cell carcinoma represent a high-risk group. Arch Dermatol. 1998;134:373.

23. Benamar L, Azzouzi S, Janati K, Benchikhi H, Lakhdar H. Axillary basal cell carcinoma: a rare localization. Ann Dermatol Venereol. 2005;132:191.

24. Wadhera A, Fazio M, Bricca G, Stanton 0. Metastatic basal cell carcinoma: a case report and literature review. How accurate is our incidence data? Dermatol Online J. 2006;12:7.

25. Abulafia J. Epiteliomas cutâneos: ensayo de classificación histogenética. An Bras Dermatol. 1963;38:14-31.

26. Youssef KK, Van Keymeulen A, Lapouge G, Beck B, Michaux C, Achouri Y, et al. Identification of the cell lineage at the origin of basal cell carcinoma. Nat Cell Biol. 2010;12:299-305.

27. Armstrong BK, Kricker A. The epidemiology of UV induced skin cancer. J Photochem Photobiol B. 2001;63:8-18. 
28. Donovan J. Review of the hair follicle origin hypothesis for basal cell carcinoma Dermatol Surg. 2009;35:1311-23.

29. Betti R, Facchetti M, Menni S, Crosti C. Basal cell carcinoma of the sole. J Dermatol. 2005;32:450-3.

30. Nüsslein-Volhard C, Wieschaus E. Mutations affecting segment number and polarity in Drosophila. Nature. 1980;287:795-801.

31. Tang JY. Elucidating the role of molecular signaling pathways in the tumorigenesis of basal cell carcinoma. Semin Cutan Med Surg. 2011;30:S6-9.

32. Bejsovec A, Peifer M. Knowing your neighbors: Cell interactions determine intersegmental patterning in Drosophila. Trends Genet. 1992;8:243-249.

33. Varjosalo M, Taipale J. Hedgehog: functions and mechanisms. Genes Dev. 2008:22:2454-72

34. Pasca di Magliano M, Hebrok M. Hedgehog signalling in cancer formation and maintenance. Nat Rev Cancer. 2003;3:903-11.

35. Dassule HR, Lewis P, Bei M, Maas R, McMahon AP. Sonic hedgehog regulates growth and morphogenesis of the tooth. Development. 2000;127:4775-85.

36. Heretsch P, Tzagkaroulaki L, Giannis A. Modulators of the hedgehog signaling pathway. Bioorg Med Chem. 2010;18:6613-24.

37. Mahindroo N, Punchihewa C, Fujii N. Hedgehog-Gli signaling pathway inhibitors as anticancer agents. J Med Chem. 2009;52:3829-45.

38. Berman DM, Karhadkar SS, Maitra A, Montes De Oca R, Gerstenblith MR, Briggs $\mathrm{K}$, et al. Widespread requirement for Hedgehog ligand stimulation in growth of digestive tract tumours. Nature. 2003;425:846-51.

39. Thayer SP, di Magliano MP, Heiser PW, Nielsen CM, Roberts DJ, Lauwers GY, et al. Hedgehog is an early and late mediator of pancreatic cancer tumorigenesis. Nature. 2003;425:851-6.

40. Ma X, Chen K, Huang S, Zhang X, Adegboyega PA, Evers BM, et al. Frequent activation of the hedgehog pathway in advanced gastric adenocarcinomas Carcinogenesis. 2005;26:1698-705

41. Yanai K, Nagai S, Wada J, Yamanaka N, Nakamura M, Torata N, et al. Hedgehog signaling pathway is a possible therapeutic target for gastric cancer. J Surg Oncol. 2007;95:55-62

42. He HC, Chen JH, Chen XB, Qin GQ, Cai C, Liang YX, et al. Expression of hedgehog pathway components is associated with bladder cancer progression and clinical outcome. Pathol Oncol Res. 2012;18:349-55.

43. Heretsch P, Tzagkaroulaki L, Giannis A. Modulators of the hedgehog signaling pathway. Bioorg Med Chem. 2010;18:6613-24.

44. Varjosalo M, Taipale J. Hedgehog: Functions and mechanisms. Genes Dev. 2008;22:2454-72

45. Johnson RL, Rothman AL, Xie J, Goodrich LV, Bare JW, Bonifas JM, et al. Human homolog of patched, a candidate gene for the basal cell nevus syndrome. Science. 1996;272:1668-71.

46. Wong SY, Reiter JF. The primary cilium at the crossroads of mammalian hedgehog signaling. Curr Top Dev Biol. 2008;85:225-60.

47. Amakye D, Jagani Z, Dorsch M. Unraveling the therapeutic potential of the Hedgehog pathway in cancer. Nat Med. 2013;19:1410-22.

48. Han J, Kraft P, Colditz GA, Wong J, Hunter DJ. Melanocortin 1 receptor variants and skin cancer risk. Int J Cancer. 2006;119:1976-84.

49. Gorlin RJ. Nevoid basal cell carcinoma syndrome. Dermatol Clin. 1995:13:113-25

50. Gailani MR, Ståhle-Bäckdahl M, Leffell DJ, Glynn M, Zaphiropoulos PG, Pressman $\mathrm{C}$, et al. The role of the human homologue of Drosophila patched in sporadic basal cell carcinomas. Nat Genet. 1996;14:78-81.

51. Xie J, Murone M, Luoh SM, Ryan A, Gu Q, Zhang C, et al. Activating smoothened mutations in sporadic basal-cell carcinoma. Nature. 1998;391:90-2.

52. Atwood SX, Whitson RJ, Oro AE. Advanced treatment for basal cell carcinomas. Cold Spring Harb Perspect Med. 2014;4:a013581.

53. Athar M, Li C, Kim AL, Spiegelman VS, Bickers DR. Sonic hedgehog signaling in basal cell nevus syndrome. Cancer Res. 2014;74:4967-75.

54. Keeler RF, Binns W. Teratogenic compounds of Veratrum californicum (Dur-and). I. Preparation and characterization of fractions and alkaloids for biologic testing. Can J Biochem. 1966;44:819-28

55. Chiang C, Litingtung Y, Lee E, Young KE, Corden JL, Westphal H, et al. Cyclopia and defective axial patterning in mice lacking Sonic hedgehog gene function. Nature. 1996;383:407-13.

56. Dreier J, Dummer R, Felderer L, Nägeli M, Gobbi S, Kunstfeld R. Emerging drugs and combination strategies for basal cell carcinoma. Expert Opin Emerg Drugs. 2014:19:353-65

57. Liang M, Lv J, Chu H, Wang J, Chen X, Zhu X, et al. Vertical inhibition of PI3K/ Akt/ mTOR signaling demonstrates in vitro and in vivo anti-fibrotic activity. J Dermato Sci. 2014;76:104-11.
58. Hooper JE, Scott MP. Communicating with Hedgehogs. Nat Rev Mol Cell Biol. 2005;6:306-17.

59. Madras J, Lapointe H. Keratocystic odontogenic tumour: reclassification of the odontogenic keratocyst from cyst to tumour. J Can Dent Assoc. 2008;74:165$165 \mathrm{~h}$.

60. Madan V, Hoban P, Strange RC, Fryer AA, Lear JT. Genetics and risk factors for basal cell carcinoma. Br J Dermatol. 2006:154:5-7.

61. Oro AE, Higgins KM, Hu Z, Bonifas JM, Epstein EH Jr, Scott MP. Basal cell carcinomas in mice overexpressing sonic hedgehog. Science. 1997;276:817-21.

62. Cobourne MT, Xavier GM, Depew M, Hagan L, Sealby J, Webster Z, et al. Sonic hedgehog signalling inhibits palatogenesis and arrests tooth development in a mouse model of the nevoid basal cell carcinoma syndrome. Dev Biol. 2009;331:38-49.

63. Hahn H, Wicking C, Zaphiropoulous PG, Gailani MR, Shanley S, Chidambaram A, et al. Mutations of the human homolog of Drosophila patched in the nevoid basal cell carcinoma syndrome. Cell. 1996;85:841-51.

64. Stacey SN, Sulem P, Masson G, Gudjonsson SA, Thorleifsson G, Jakobsdottir M, et al. New common variants affecting susceptibility to basal cell carcinoma. Nat Genet. 2009;41:909-14.
MAILING ADDRESS:

Erik Montagna

Av. Lauro Gomes, 2000

Vila Sacadura Cabral

09060-870 - Santo André, SP

Brazil

Email: erik_montagna@yahoo.com

How to cite this article: Montagna E, Lopes OS. Molecular basis of basal cell carcinoma. An Bras Dermatol. 2017;92(4):517-20. 